an open scholarship in mathematics to Trinity College, Cambridge, in 1934 and was a wrangler, taking a first in Part 2 and passing with distinction Part 3 of the Mathematical Tripos. He joined the B.C.U.R.A. in 1938 and was appointed head of the Mathematics and Mechanics Department in 1946 and superintendent of the Physics Department in 1949. He is a Fellow of the Institute of Fuel and of the Institute of Physics and was awarded the Students Medal of the Institute of Fuel in 1939. He is a member of the Publication Committee of these Institutes and was chairman of the Organizing Committee of the Institute of Fuel Conference on "Science in the Use of Coal", and from 1956 until 1960 was honorary secretary of the Committee of Directors of Research Associations. He, and Mr. Hicks, will take up their new posts on October 1 .

\section{Great Britain and Space Research}

Is a written answer in the House of Commons on July 30 the Minister of Aviation, Mr. J. Amery, stated that the United Kingdom, together with Australia, Belgium, France, the Federal Republic of Germany, Italy and the Netherlands, was participating in the development of a three-stage satellite launcher by the European Launcher Development Organiza. tion. A preparatory group had been set up to coordinate the work proceeding in the member countries, pending the ratification of the Convention to establish the Organization. A technical mission was at present in Australia examining the problems connected with firing the Blue Streak first stage and the three-stage launcher from the Woomera Range. The PostmasterGeneral, Mr. J. R. Bevins, stated on July 31 that the Post Office expected to spend about $£ 700,000$ in 1962-63 on the development of communications by means of artificial satellites, and tentatively provision of $£ 1$ million was provided in each of the next four years.

On August 2 it was stated by Lord Hailsham in the House of Lords and by the Parliamentary Secretary for Science in the House of Commons that a Space Research Management Group was set up under the Office of the Minister for Science, with effect from May 1, 1962, which had assumed the responsibilities for the management of the programme of experiments in rockets and satellites, previously discharged under ad hoc arrangements by two scientists and one engineer on loan to the Royal Society from the public services. The new Group would comprise these three officers, five additional officers and supporting staff. This is an ad hoc arrangement pending the outcome of the present inquiry into Government and scientific organization and had been introduced in agreement with the Royal Society. The British National Committee on Space Research, set up by the Royal Society, would continue to advise on the scientific content of the programme and the Steering Group on Space Research would continue to advise the Minister on policy matters in its field. In the House of Commons, Mr. Freeth added that the massive flow of coded data from the satellite Ariel would take time to process and analyse. Those concerned with the experiments were not yet ready to express considered views although they had indicated that much interesting and valuable information about the structure of the ionosphere and the constitution of the high atmosphere was now available. Recently, transmission of data had been interrupted irregularly and the reason for this was being investigated.

\section{Nuclear Power Reactors in Britain}

IN written replies to questions in the House of Commons on July 31, the Parliamentary Secretary for Science, Mr. D. Freeth, stated that the Atomic Energy Authority had spent about $£ 10$ million on the development of beryllium as a canning material for advanced gas-cooled reactor fuel. Including supporting services, 630 people were employed on the Dounreay fast reactor. Comprehensive inspection during the five and a half years since the first nuclear power station at Calder Hall came into operation had given no evidence that the life of magnox stations would be limited to 20 years; there was as yet no final proof of the life of a reactor, but an assumption of 30 years could be as realistic as 20 , particularly for the later stations in the programme.

\section{Professional Qualifications and the European Com-} munity

Is a debate in the House of Lords on Britain and the Common Market on August 1, Lord Cohen of Birkenhead directed attention to the implications of the Treaty of Rome for all those professions which require a qualification registrable by law. Section 1 of Article 57 empowers the Council to issue directions regarding mutual recognition of certificates, diplomas and other qualifications. Lord Cohen was concerned that in consequence a medical or other professional qualification obtained in any of the member States of the European Economic Community would be acceptable as a criterion of a registered medical practitioner. Although vice versa British qualifications would be recognized by the 'Six', Lord Cohen said that on account of the wide disparity in standards of medical qualification and practice among members of the European Economic Community this Article had given rise to grave disquiet in the medical, dental and para-medical professions in Britain. Lord Cohen entered no claim for any sectional interest but was concerned at the effect on the public interest of any debasing of professional standards. In replying on the debate, the Lord Chancellor pointed out that the Council of Ministers could only issue directives for the mutual recognition of qualifications on proposals made to them by the Commission and after consulting the European Assembly. Such directives had no effect for the medical, para-medical and pharmaceutical professions, until conditions for the exercise of these conditions had been co-ordinated. Further voting on these matters must be unanimous and he thought that these were substantial safeguards. The Government understood the importance of this subject, and if Britain joined the Community the Government would keep in close touch with the General Medical Council and all other interested bodies, while playing her part in the Community's proceedings. Regard would be had, as the General Medical Council had urged, to the standards achieved in Britain.

\section{The Commonwealth Development Corporation}

The Minister of State for Colonial Affairs, Lord Lansdowne, announced in the House of Lords on July 31 that it had been decided to extend the activities of the Colonial Development Corporation which have hitherto been confined to dependent territories. It is proposed henceforth to authorize the Corporation to undertake new development schemes in countries in which it was previously empowered to operate even after they have become independent members of the Commonwealth. The 